\title{
ХАРАКТЕРИСТИКА ПРИНЦИПІВ АДМІНІСТРАТИВНОӤ ПРОЦЕДУРИ З НАДАННЯ ПУБЛІЧНИХ ПОСЛУГ У СФЕРІ ДЕРЖАВНОЇ РЕССТРАЦIÏ РЕЧОВИХ ПРАВ НА НЕРУХОМЕ МАЙНО
}

\author{
МАРТИНЮК Наталія Миколаївна - здобувач кафедри адміністративного \\ та митного права Університету митної справи та фінансів
}

УДК: 342.95

https://orcid.org/0000-0001-7623-2260

DOI 10.32782/EP.2020.3.22

Научная статья посвящена освещению принципов административной процедурь по предоставлению публичньхх услуг в сфере государственной регистрации прав на недвижимое имущество. К общим приниипам административной процедуръ по предоставлению публичнъгх услуг в сбере государственной регистрации прав на недвижимое имущество необходимо отнести: свободъ въгбора, системности, гуманизма, демократизма и научности территориально-отраслевой, непрерьлности, целеустремленности, экономической целесообразности, результативности, профессионализма, ответственности, доступности, единства, иентрализации (подчиненности), удобства, своевременности и зонально-предметнъий и тому подобное.

Согласно специальных приниципов административной процедуры по предоставлению публичньхх услуг в сбере государственной регистрации прав на недвижимое имущество необходимо отнести: 1) сведение к рациональному минимуму количества документов и проиедурных действий, которье требуются для предоставления административных услуг;2) внедрение новъгх организационных борм оказания административных услуг (универсамов услуг, единъих обисов и т.п.), более удобньих для фбизических и юридических лич; 3) постоянного мониторинга качества предоставления административньхх услуг.

Приниипь по государственной регистраици прав на недвижимое имущество обеспечивают интеграцию отдельньх их видов в различных органах (подразделениях), взаимную их согласованность и общее направление на реализачию общей цели - обеспечение реализаици законньгх прав и интересов бизических и юридических лии.

Доказано, что приницив предоставления публичных услуг в сбере государственной регистрачии прав на недвижимое имущество является системой, то есть взаимосвязанньми и взаимозависимъими. Поэтому нарушение одного из них может привести к нарушению других. Качество предоставления публичньх услуг достигается последовательным применением всей системъ приниипов и каждого из них в отдельности.

Ключевъие слова: услуга, публичная услуга, процедура, стадия, приниипов административной прочедуръг по предоставлению публичнъгх услуг в сбере государственной регистраизии прав на недвижимое имущество.

\section{Постановка проблеми}

Забезпечення демократизації життя українського суспільства вимагає від працівників органів внутрішніх справ України вжиття заходів, спрямованих на реалізацію положень ст. 3 Конституції України щодо відповідальності держави перед громадянами за свою діяльність і належний захист прав та свобод людини [1, ст. 141].

\section{ОгАяд останніх досліджень та публікацій}

Нині, завдяки науковим працям В.Б. Авер'янова, Ю.П. Битяка, В.М. Гаращука, І.П. Голосніченка, К.К. Афанасьєва, 
С.В. Ківалова, І.Б. Коліушка, А.Т. Комзюка, О.В. Кузьменко, С.О. Аегези, Г.М. Писаренко, В.П. Тимощука та інших науковців, досліджено ряд особливостей діяльності органів публічної влади з надання публічних, у тому числі публічних послуг у сфері державної реєстрації речових прав на нерухоме майно населенню. На цей час у наукових дослідженнях питання надання публічних послуг органами публічної адміністрації майже не вивчались.

Метою даної статті є висвітлення принципів адміністративної процедури з надання публічних послуг у сфері державної реєстрації речових прав на нерухоме майно.

Для вирішення мети автором поставлені такі завдання: 1) розглянути загальні принципи принципів адміністративної процедури з надання публічних послуг у сфері державної реєстрації речових прав на нерухоме майно органами публічної адміністрації; 2) охарактеризувати спеціальні принципи принципів адміністративної процедури з надання публічних послуг у сфері державної реєстрації речових прав на нерухоме майно.

\section{Виклад основного матеріалу}

Аналізуючи загальні принципи українського адміністративного права, В. Б. Авер'янов, Ю. П. Битяк, В. В. Зуй доходять висновку, що вони закріплені в Конституції України й конкретизуються і розвиваються в законодавчих та інших нормативно-правових актах. До таких науковці відносять: 1) принцип пріоритету прав і свобод людини та громадянина; 2) принцип верховенства права та правового закону; 3) принцип рівності однорідних суб’єктів адміністративного права перед законом; 4) принцип демократизму; 5) принцип взаємної відповідальності суб'єктів публічної адміністрації і об'єктів публічного управління; 6) принцип гуманізму і справедливості у взаємовідносинах між суб'єктами публічної адміністрації та об'єктами публічного управління [7, с. 82].

Принципи принципів адміністративної процедури 3 надання публічних послуг у сфері державної реєстрації речових прав на нерухоме майно органами виконавчої влади та місцевого самоврядування взаємодіють між собою в межах цілісної системи, врівноважуючи чи посилюючи один одного, що дає змогу достатньою мірою розкрити їх природу, індивідуальність і регулюючі можливості. При цьому кожен принцип займає структурно відведене йому місце що дає підстави зробити висновок - повноцінне розкриття змісту і потенціалу будь-якого принципу можливе лише в рамках і з урахуванням його системних залежностей.

На сьогодні окремо немає законодавчих актів, що стосуються принципів надання публічних послуг, проте є Закон України «Про адміністративні послуги», «Про соціальні послуги», «Про державну реєстрацію речових прав на нерухоме майно та їх обтяжень» тощо, у яких зазначаються різні види публічних послуг, таких як: адміністративні, соціальні, поліцейські послуги тощо.

Так, у Законі України «Про адміністративні послуги» зазначаються принципи надання публічних послуг у сфері державної реєстрації речових прав на нерухоме майно [5], але не міститься розподілу цих принципів на загальні та спеціальні, що призводить до незрозумілого дублювання з іншими нормативно-правовими актами.

На нашу думку, відповідно до вищевказаного закону принципи надання адміністративних, у тому числі і публічних послуг у сфері державної реєстрації речових прав на нерухоме майно, до загальних потрібно віднести такі: законності; оперативності та своєчасності; загальнодоступності правової та іншої необхідної інформації; неупередженості та справедливості; юридичної відповідальності адміністративних органів та їх посадових осіб. Також до загальних принципів необхідно добавити ще такі основи, як: свободи вибору, системності, гуманізму, демократизму та науковості територіально-галузевий, безперервності, цілеспрямованості, економічної доцільності, результативності, професійності, відповідальності, доступності, єдності, централізації (підпорядкованості), зручності, своєчасності та зонально-предметний.

Відповідно до спеціальних принципів 3 вищевказаного закону необхідно віднести: 


\section{Цивільне, підприсмницьке, господарське та трудове право}

1) юридичної визначеності, що полягає у необхідності визначати безпосередньо у законодавчому акті деякі види діяльності як адміністративні послуги, а деякі процедури — як особливості надання публічних послуг у сфері державної реєстрації речових прав на нерухоме майно; 2) зведення до раціонального мінімуму кількості документів та процедурних дій, що вимагаються для надання публічних послуг у сфері державної реєстрації речових прав на нерухоме майно; 3) впровадження нових організаційних форм надання публічних послуг у сфері державної реєстрації речових прав на нерухоме майно (універсамів послуг, єдиних офісів тощо), більш зручних для фізичних та юридичних осіб; 4) постійного моніторингу якості надання публічних послуг у сфері державної реєстрації речових прав на нерухоме майно.

Охарактеризуємо тільки основні положення спеціальних принципів надання публічних послуг у сфері державної реєстрації речових прав на нерухоме майно, адже загальні принципи вже розглядалися неодноразово науковцями різних спеціальностей.

Так, юридичної визначеності, що полягає у необхідності визначати безпосередньо у законодавчому акті деякі види діяльності як публічні послуги у сфері державної реєстрації речових прав на нерухоме майно, а деякі процедури - як особливості надання публічних послуг принцип надання органами публічної адміністрації публічних послуг у сфері державної реєстрації речових прав на нерухоме майно полягає в тому, що, як правило, публічні послуги надаються за місцем проживання (реєстрації) фізичних чи за юридичною адресою (місцем реєстрації) юридичних осіб.

Принцип безперервності полягає в постійному наданні суб'єктами публічних послуг. Організацію такої діяльності ні в якому разі не можна розглядати як короткочасну кампанію, розраховану лише на вирішення якогось конкретного завдання. Пропозиція щодо доцільності надання публічних послуг органами влади не менше як п'ять разів у тиждень, у робочі, після робочі години та в один із вихідних днів була обгрунтована вже неодноразово різними авторами.
Принцип результативності передбачає спрямованість суб'єктів надання публічних послуг на позитивне вирішення справи, тобто на надання особі публічної послуги. Результативність також передбачає орієнтацію на цілісність послуги, тобто отримання особою загального очікуваного результату.

Принцип доступності передбачає фактичну можливість особи звернутися за отриманням публічної послуги. Доступність включає: наявність інформації про орган, який надає відповідні публічні послуги, іiі достатність (повноту) та коректність; різноманітність та доступність джерел такої інформації, у тому числі можливість отримання інформації телефоном, через мережу Iнтернет; територіальну наближеність органу до споживачів послуг; можливість вільного (безперешкодного) доступу споживачів послуг в приміщення адміністративного органу; наявність та безкоштовність бланків та інших формулярів, необхідних для звернення за публічною послугою, можливість отримання таких бланків з веб-сторінки органів публічної адміністрації; справедливий (обгрунтований) розмір плати за публічну послугу (якщо послуга платна).

Принцип иентралізациї (підпорядкованості) визначає організуючий, забезпечуючий та координуючий характер надання публічних послуг відповідних суб'єктів. Так, окремими нормативними актами МВС встановлено особливий порядок візування вищестоящими органами матеріалів 3 питань дозвільної діяльності які підготовлені нижчестоящими підрозділами [2; 3]. Цей принцип зумовлює необхідність постійно координувати діяльність, підпорядкованих підрозділів, враховувати місце (компетенцію) кожної з них, застосовувати різноманітні методи узгодження цієї діяльності для регулярного підвищення ефективності принципів адміністративної процедури 3 надання публічних послуг у сфері державної реєстрації речових прав на нерухоме майно органами публічної адміністрації.

Принцип зручності передбачає врахування інтересів та потреб споживачів послуг. Зручність включає: можливість вибору способу звернення за публічною послугою, у тому числі забезпечення можливості 
звернення поштою, електронною поштою тощо; мінімізацію кількості інстанцій, залучених до надання публічної послуги; максимальний обсяг та зручність для споживачів часу особистого прийому громадян, чітку визначеність цього часу та його реальне дотримання; відсутність черг або впорядкованість (організованість) особистого прийому громадян, використання механізмів попереднього запису, прозорої (нумерованої) черги тощо; зручний порядок оплати публічної послуги (якщо послуга платна).

Своєчасність як один із принципів надання публічної послуги передбачає дотримання установленого терміну надання публічної послуги з орієнтацією на якнайшвидше вирішення справи. Орган, що надає публічну послугу у сфері державної реєстрації речових прав на нерухоме майно, повинен враховувати законні інтереси особи щодо прискореного надання публічної послуги. Наприклад, відповідно до статті 10 Закону України «Про адміністративні послуги» зазначається, що граничний строк надання адміністративної послуги, цей строк не може перевищувати 30 календарних днів 3 дня подання суб'єктом звернення заяви та документів, необхідних для отримання послуги. Суб’єкт надання публічних послуг у сфері державної реєстрації речових прав на нерухоме майно надає публічну послугу у сфері державної реєстрації речових прав на нерухоме майно, а центр надання публічних послуг у сфері державної реєстрації речових прав на нерухоме майно забезпечує організацію надання такої послуги у найкоротший строк та за мінімальної кількості відвідувань суб'єктом звернення.

Під час здійснення державної реєстрації прав, які виникли та зареєстровані в установленому порядку до 01.01.2013 р., державний реєстратор запитує від органів виконавчої влади, органів місцевого самоврядування, підприємств, установ та організацій, які відповідно до чинного, на момент реєстрації, законодавства проводили таку реєстрацію, інформацію (довідки, копії документів тощо), необхідну для реєстрації прав та їх обтяжень, якщо такі документи не були подані заявником або якщо документи, подані заявником, не містять пе- редбачених цим Законом відомостей про правонабувача або про нерухоме майно. Суб'єкти, до яких надійшов такий запит, зобов'язані безоплатно в установленому законодавством порядку протягом 3 робочих днів надати державному реєстратору відповідну інформацію, зокрема щодо зареєстрованих речових прав на нерухоме майно, у тому числі на земельні ділянки (п. 8-1 ч. 2 ст. 9 Закону № 1952-IV).

Розгляд документів передбачає: а) встановлення відповідності заявлених прав і поданих документів вимогам законодавства: відповідність обов'язкового дотримання письмової форми правочину та його нотаріального посвідчення (у випадках, установлених законом); відповідність повноважень особи, яка подає документи на державну реєстрацію прав та їх обтяжень; наявність факту виконання умов правочину, з якими закон та/або договір (угода) пов'язує можливість здійснення державної реєстрації виникнення, переходу, припинення прав на нерухоме майно або обтяження таких прав; б) встановлення відсутності суперечностей між заявленими та уже зареєстрованими правами на нерухоме майно та їх обтяженнями, зокрема відповідність відомостей про нерухоме майно, наявних у Державному реєстрі прав та поданих документах; наявність обтяжень прав на нерухоме майно, зареєстрованих відповідно до вимог цього Закону.

На підставі розгляду документів поданих для проведення державної реєстрації державний реєстратор вирішує, чи є підстави для зупинення розгляду заяви або наявні інші підстави, за яких необхідно відмовляти у проведенні державної реєстрації прав.

У разі надання адміністративної послуги суб'єктом надання публічних послуг у сфері державної реєстрації речових прав на нерухоме майно, який діє на засадах колегіальності, рішення про надання адміністративної послуги або про відмову в їі наданні приймається у строк, визначений частиною першою або другою 10 статті закону України «Про адміністративні послуги», а в разі неможливості прийняття зазначеного рішення у такий строк - на першому засіданні 


\section{Цивільне, підприємницьке, господарське та трудове право}

(слуханні) після закінчення цього строку.

Публічна послуга у сфері державної реєстрації речових прав на нерухоме майно вважається наданою з моменту отримання iї суб'єктом звернення особисто або направлення поштою (рекомендованим листом 3 повідомленням про вручення) листа 3 повідомленням про можливість отримання такої послуги на адресу суб'єкта звернення. у випадках, передбачених законодавством, відповідний документ може бути надісланий поштою (рекомендованим листом 3 повідомленням про вручення) або за допомогою засобів телекомунікаційного зв'язку. При цьому строк доставки поштової кореспонденції не зараховується до строку надання адміністративної послуги [5]. Тобто, бачимо законодавець визначив, що більш ніж тридцять днів з моменту реєстрації заяви щодо отримання конкретної адміністративної послуги не може бути.

Принцип мовчазноӥ згоди покликаний стимулювати виконання суб'єктами владних повноважень приписів принципів своєчасності, відповідальності та результативності й передбачає право суб'єкта звернення провадити певні дії, за дозволом на провадження яких він звертався до адміністративних органів, без одержання документа дозвільного характеру через 10 робочих днів з моменту закінчення строку, встановленого для видачі документа дозвільного характеру або прийняття рішення про відмову в його видачі, на підставі копії опису прийнятих документів 3 відміткою про дату їх прийняття. На наш погляд, впровадження цього принципу в процедурну діяльність 3 державної реєстрації речових прав на нерухоме майно сприятиме оптимізації функціонування всієї системи органів 3 державної реєстрації речових прав на нерухоме майно та, в кінцевому підсумку, дозволить підвищити рівень довіри до зазначених органів з боку споживачів послуг, що є особливо важливим в умовах сьогодення.

Зупинимося на цьому принципі дещо детальніше. Як відомо, впродовж останнього десятиліття в наукових колах точаться цікаві дискусії навколо зазначеного принципу. Проблемними вважаються такі аспекти його реалізації, як можливість включи- ти в обсяг його юрисдикції всі без винятку дозвільні процедури (виняток, наприклад, згідно із Законом України «Про дозвільну систему у сфері господарської діяльності» становлять сфера дозволу на зброю, боєприпаси й вибухові речовини, цивільна авіація тощо), можливість провадження діяльності в ситуації відсутності конкретного адміністративного акта (чи може копія опису прийнятих документів слугувати адекватним за юридичною силою документом - заміною дозвільного акта), можливість зловживання цим принципом з боку несумлінних осіб для створення певних схем нелегального використання цього принципу за відсутності необхідної документації.

Безумовно, питання не виглядає простим і потребує серйозного розгляду. На наш погляд, втілення цього принципу в реальність має більше позитивних моментів, ніж приводів для побоювання, але для цього потрібно прикласти зусилля в частині нормативно-правової узгодженості адміністративно-процедурної діяльності. Цей принцип, по суті, є способом об'єктивації відомої формули "дозволено все, що не заборонено», тому відсутності заборони він надає пріоритет перед існуванням документального дозвільного акта. Однак у вітчизняній адміністративній традиції змістовну вагу має саме індивідуальний акт. Тому пропонуємо такі кроки: перш за все, вищезгадану «копію опису прийнятих документів» потрібно документально оформити як окремий акт - наприклад, «попередній дозвіл» - і нормативно закріпити, що в разі затримки з одержанням документа дозвільного характеру на зазначений строк (10 днів 3 моменту строку передбачуваної видачі дозвільного акта) без попередження з боку публічних органів на підставі цього документа може провадитись певна діяльність. Подруге, слід нормативно зобов'язати органи адміністрації в разі виникнення сумнівів у достовірності наданих суб'єктом звернення документів, їх узгодженості або потреби в додатковій інформації своєчасно сповіщати про це суб'єкта звернення в будь-який зручний для нього спосіб. Це стимулюватиме суб'єктів надання щодо державної реєстрації речових прав на нерухоме майно 
як до додержання строків їх надання, встановлених законодавчо, так і до підсилення «зворотного зв’ язку» із суб'єктами отримання, що у підсумку сприятиме оптимізації функціонування всієї адміністративно-послугової системи.

Стосовно побоювань у зловживанні дією цього принципу можна зазначити, що, наприклад, у разі початку господарської діяльності на підставі «попереднього дозволу» особа, якій потім (хоча й із затриманням у часі) буде на законних підставах відмовлено в отриманні бажаного дозвільного документа, підпадає під дію Кодексу України про адміністративні правопорушення і може понести відповідальність у вигляді стягнення штрафу і конфіскації виготовленої продукції, знарядь виробництва та сировини [2]. Тому, вважаємо, суб'єкти господарювання заздалегідь попереджені публічними органами про те, що затягування строків надання послуги викликано об'єктивними причинами, будуть уявляти собі ступінь можливих наслідків і ризик початку діяльності без остаточного рішення. У такий спосіб, на наш погляд, комунікація між суб'єктами звернень і суб'єктами надання послуг відбуватиметься на основі прозорості, відповідальності і, врешті-решт, довіри.

\section{Висновки}

Таким чином, принципи є тією основою, на базі якої організується процедура 3 державної реєстрації речових прав на нерухоме майно, тобто науково обгрунтоване впровадження дій для здійснення розпорядчо-владних функцій, вибору методів і прийомів надання адміністративних послуг. Принципи з державної реєстрації речових прав на нерухоме майно забезпечують інтеграцію окремих їх видів у різних органах (підрозділах), взаємну їх погодженість і загальне спрямування на реалізацію загальної мети - забезпечення реалізації законних прав та інтересів фізичних та юридичних осіб [4, с. 43].

Принципи надання публічних послуг у сфері державної реєстрації речових прав на нерухоме майно є системою, тобто взаємопов'язаними та взаємозалежними. Тому порушення одного 3 них може при- звести до порушення інших. Якість надання публічних послуг досягається послідовним застосуванням усієї системи принципів і кожного $з$ них окремо.

\section{Література}

1. Конституція України. Відомості Верховної Ради України. .1996. .№ 30. Ст. 141.

2. Адміністративне право України: академічний курс : [підруч. для студ. юрид. спец. вищих навч. закл. : у 2 т. /В. Б. Авер'янов, О. Ф. Андрійко, Ю. П. Битяк та ін. ; гол. редкол. В. Б. Авер'янов]. К. : Юридична думка, 2004. Т. 2 : Особлива частина. 583 с.

3. Про затвердження Інструкції про порядок розгляду звернень та особистого прийому громадян у Міністерстві юстиції України, в установах та організаціях, що належать до сфери його управління : наказ Міністерства юстиції України від 18.03.2004 № 26/5/ Мін’юст України. Оббіиійний вісник Украӥни від 09.04.2004 - 2004 р., № 12, том 1, стор. 261, стаття 777, код акту 28242/2004.

4. Острах М. Б. Провадження 3 надання адміністративних послуг в Україні. Автореф. дис. . канд. юрид. наук : 12.00.07. Міжн. університет бізнесу і права. Херсон, 2013. $20 \mathrm{c}$

5. Про адміністративні послуги : Закон України від 06.09.2012 № 5203-VI. Верховна Рада України. Відомості Верховної Ради Украйни. 2013. № 32. Ст. 409.

6. Тимощук В. П. Адміністративна процедура та адміністративні послуги. Зарубіжний досвід і пропозиції для України. К.: Факт, 2003. 496 с.

7. Битяк Ю. П. Административное право Украины [учебник для студентов высш. учеб, заведений юрид. спец. ]. 2-е изд., перераб. и доп. Х.: Право, 2003. 576 с.

8. Хаксевер К. Управление и организация в сфере услуг / Хаксевер К., Рендер Б., Рассел Р., Мердик Р.; пер. с англ. под ред. В. В.Кулибановой. - 2-е изд. СПб.: Питер, 2002. 752 c.

9. Аегеза E. О. Характеристика принципів провадження 3 надання публічних послуг. Актуальні проблеми вітчизняної юриспрудениї. 2016. № 2. С. 90-92. 


\section{Цивільне, підприсмницьке, господарське та трудове право}

\section{АНОТАЦІЯ}

Наукова стаття присвячена висвітленню принципів адміністративної процедури 3 надання публічних послуг у сфері державноі реєстрачій речових прав на нерухоме майно. До загальних приниипів адміністративної процедури з надання публічних послуг у сфері державної реєстрачї речових прав на нерухоме майно необхідно віднести: свободи вибору, системності, гуманізму, демократизму та науковості територіально-галузевий, безперервності, иілеспрямованості, економічної доиільності, результативності, професійносmi, відповідальності, доступності, єдності, иентралізаиій (підпорядкованості), зручності, своєчасності та зонально-предметний тощо.

Відповідно до спещіальних приниипів адміністративної процедури з надання публічних послуг у сфоері державной реєстрачій речових прав на нерухоме майно необхідно віднести:1) зведення до раціонального мінімуму кількості документів та процедурних дій, що вимагаються для надання адміністративних послуг; 2) впровадження нових організачійних борм надання адміністративних послуг (універсамів послуг, єдиних оббісів тощо), більш зручних для фбізичних та юридичних осіб; 3) постійного моніторингу якості надання адміністративних послуг.

Принщипи з державної реєстращиї речових прав на нерухоме майно забезпечують інтеграцію окремих їх видів у різних органах (підрозділах), взаємну їх погодженість $i$ загальне спрямування на реалізацію загальної мети забезпечення реалізачиї законних прав та інтересів фізичних та юридичних осіб.

Доведено, що приниипи надання публічних послуг у сфері державної реєстрачиї речових прав на нерухоме майно є системою, тобто взаємопов'язаними та взаємозалежними. Тому порушення одного з них може призвести до порушення інших. Якість надання публічних послуг досягається послідовним застосуванням усієї системи принципів $i$ кожного $з$ них окремо.

Ключові слова: послуга, публічних послуга, процедура, стадія, принципів адміністративної процедури з надання публічних послуг у сбері державної реєстрачиї речових прав на нерухоме майно.
The scientific article is devoted to the coverage of the principles of the administrative procedure for the provision of public services in the field of state registration of real property rights. The general principles of the administrative procedure for the provision of public services in the field of state registration of real property rights include: freedom of choice, system, humanism, democracy and scientific territorial-sectoral, continuity, purposefulness, economic feasibility, efficiency, professionalism, responsibility, accessibility, unity, centralization (subordination), convenience, timeliness and zonalsubject, etc.

In accordance with the special principles of the administrative procedure for the provision of public services in the field of state registration of real property rights must include: 1) minimization of the number of documents and procedural actions required for the provision of administrative services; 2) introduction of new organizational forms of providing administrative services (service supermarkets, single offices, etc.), more convenient for individuals and legal entities; 3) constant monitoring of the quality of administrative services.

Principles of state registration of real rights to immovable property ensure the integration of their individual species in different bodies (units), their mutual agreement and a common focus on the common goal - to ensure the realization of legal rights and interests of individuals and legal entities.

It is proved that the principles of providing public services in the field of state registration of real property rights are a system, ie interconnected and interdependent. Therefore, violation of one of them can lead to violation of others. The quality of public services is achieved through the consistent application of the entire system of principles and each of them separately.

Key words: service, public service, procedure, stage, principles of administrative procedure for providing public services in the field of state registration of real property rights. 